\title{
Fat-reduced diet in the treatment of hyperoxaluria in patients with ileopathy
}

\author{
HENRIK ANDERSSON AND RUDOLF JAGENBURG \\ From the Department of Clinical Nutrition and Clinical Chemistry, University of Göteborg, Göteborg, \\ Sweden
}

SUMMARY Thirteen patients with ileopathy were studied under metabolic ward conditions, first on a 100-g fat diet and later on a 40-g fat diet. Ten of the patients were studied after three to 27 months on a fat-reduced diet. Ten of the patients had a high urinary oxalate excretion on the high-fat diet compared with a control group. The patients with a faecal fat output of more than $15 \mathrm{~g}$ a day showed a reduction in oxalate excretion when the fat intake was decreased and in the follow-up study the oxalate excretion was low in all patients except in one with a remaining steatorrhoea. There was a correlation between urinary oxalate excretion and faecal output of fatty acids. It is postulated that a low intraluminal calcium ion concentration, mainly caused by the high fatty acid content, explains the hyperoxaluria. The low fat diet, which also reduced the diarrhoea and increased the urinary output, was acceptable to the patients. The diet is recommended for patients with ileopathy in order to reduce the risk of formation of renal calculi.

Hyperoxaluria and nephrolithiasis may occur in patients with ileopathy (Smith, Hofmann, McCall, and Thomas, 1970; Dowling, Rose, and Sutor, 1971; Admirand, Earnest, and Williams, 1971). Abnormalities in the bile salt metabolism (Hofmann, Thomas, Smith, and McCall, 1970; Smith, Fromm, and Hofmann, 1972), a preferential conversion of glyoxylate to oxalate in the liver (Admirand et al, 1971), and an increased absorption of dietary oxalate (Chadwick, Modha, and Dowling, 1973; Stauffer, Humphreys, and Weir, 1973) have been proposed to explain this secondary form of hyperoxaluria. These theories have resulted in different therapeutic applications. A decrease in urinary oxalate after oral taurine has been found in some studies (Dowling et al, 1971; Admirand et al, 1971) but questioned in others (Smith et al, 1972; Chadwick et al, 1973). Cholestyramine has also been shown to reduce the oxalate excretion to normal (Smith $e t$ al, 1972; Stauffer et al, 1973). Finally, a low oxalate diet has been proposed by Chadwick et al (1973).

Andersson, Isaksson, and Sjögren (1974) have shown that reduction of the fat intake in patients with ileopathy results in a decrease in the diarrhoea, steatorrhoea, and faecal loss of water and electrolytes. Urinary samples from the patients studied by

Received for publication 18 February 1974. these authors under metabolic ward conditions were available and have been used for quantitative determination of oxalate excretion. In the present investigation the effect of the reduced fat diet on the urinary oxalate excretion in these patients will be reported. A hypothesis for the beneficial effect of the fatreduced diet will also be presented.

\section{Material}

The material consists of urine from 13 patients (six women and seven men), mean age 38 years, with ileopathy described earlier in detail (Andersson $\boldsymbol{e t}$ $a l$, 1974) (table I). All patients complained of watery bowel evacuations. In patient M 210 distal ileum had been removed at an operation for ileus caused by irradiation damage to the gut. One patient, M 170, had had a resection of the ileum after an accident. The remaining 11 patients had Crohn's disease with ileal involvement, and in nine of them ileal resection had been performed. Two patients, M 158 and M 210, had previously had renal calculi.

The patients had been studied under metabolic ward conditions (Isaksson and Sjögren, 1967). This initial study consisted of eight to 16 days with a daily intake of $100 \mathrm{~g}$ fat, followed by 12 to 24 days with a daily intake of $40 \mathrm{~g}$ fat. The diets were individually composed. 


\begin{tabular}{|c|c|c|c|c|c|c|c|c|}
\hline \multirow[t]{2}{*}{ Patient } & \multirow[t]{2}{*}{ Sex } & \multirow[t]{2}{*}{ Age: } & \multirow[t]{2}{*}{ Diagnosis } & \multirow{2}{*}{$\begin{array}{l}\text { Duration } \\
\text { of } \\
\text { Symptoms } \\
(y r)\end{array}$} & \multicolumn{2}{|c|}{$\begin{array}{l}\text { Length of Small } \\
\text { Bowel Resection }\end{array}$} & \multirow[t]{2}{*}{ Anastomosis } & \multirow{2}{*}{$\begin{array}{l}\text { Faecal Fat } \\
\text { on } 100-8 \\
\text { Fat Diet } \\
(\mathrm{g} / 24 \mathrm{hr})\end{array}$} \\
\hline & & & & & $\begin{array}{l}\text { Jejunum } \\
(\mathrm{cm})\end{array}$ & $\begin{array}{l}\text { Ileum } \\
(\mathrm{cm})\end{array}$ & & \\
\hline M 210 & $\mathbf{F}$ & 63 & Ileus & 13 & & 55 & Ileum-caecum & 55 \\
\hline M 170 & $\mathbf{M}$ & 52 & Trauma & 6 & & 135 & Ileum-caecum & 42 \\
\hline M 209 & $\mathbf{F}$ & 33 & Crohn's disease & 18 & & 125 & Ileum-ascending colon & 37 \\
\hline M 191 & $\mathbf{M}$ & 33 & Crohn's disease & 7 & & 140 & Ileostomy & 29 \\
\hline M 203 & $\mathbf{F}$ & 61 & Crohn's disease & 16 & & 100 & Ileum-transverse colon & 28 \\
\hline M 216 & $\mathbf{M}$ & 34 & Crohn's disease & 10 & 40 & 150 & Ileum-transverse colon & 22 \\
\hline M 195 & $\mathbf{M}$ & 19 & Crohn's disease & 2 & & & & 19 \\
\hline M 158 & $\mathbf{M}$ & 61 & Crohn's disease & 36 & & 35 & Ileum-transverse colon & 19 \\
\hline M 198 & $\mathbf{M}$ & 27 & Crohn's disease & 13 & & 125 & Ileum-transverse colon & 13 \\
\hline M 179 & $\mathbf{F}$ & 38 & Crohn's disease & 9 & & 60 & Ileum-transverse colon & 11 \\
\hline M 164 & $\mathbf{F}$ & 27 & Crohn's disease & 18 & & 50 & Ileum-caecum & 9 \\
\hline M 211 & $\mathbf{F}$ & 24 & Crohn's disease & 2 & & & & 6 \\
\hline M 185 & $\mathbf{M}$ & 25 & Crohn's disease & 10 & 160 & 35 & Ileum-transverse colon & 5 \\
\hline
\end{tabular}

Table I Clinical data and faecal fat excretion in the present series of patients

On the 100-g fat diet most patients had steatorrhoea (table I). On the fat-reduced diet there was a reduction in the number of bowel evacuations and a decrease in the faecal content of fat, water, potassium, and sodium (Andersson et al, 1974). Treatment with the fat-reduced diet was continued at home. Three to 27 months later a follow-up study was performed. Ten of the 13 patients were admitted to the metabolic ward (four days) and were given the 40-g fat diet. One of the initial patients had died of intercurrent disease and two patients had been operated upon again and were thus discharged from the follow-up study.

The urines from patients with ileopathy consisted of 111 samples out of the total of 115 samples collected quantitatively in four-day periods during the metabolic studies. Thirty-four samples were collected during the high-fat regime, 67 samples during the initial low-fat study, and 10 samples during the follow-up study.

The control material consisted of one 24-hour collection of urine from each of 13 apparently healthy subjects matched for age and sex.

\section{Methods}

\section{URINARY OXALATE}

The urine was transferred directly after voiding into flasks containing $5 \mathrm{~N}$ hydrochloric acid $(10 \mathrm{ml} / 24 \mathrm{hr})$. Four-day portions were collected and aliquots were stored at $-16^{\circ} \mathrm{C}$ until assayed. The oxalate was measured on centrifuged urine thawed at $+4^{\circ} \mathrm{C}$ overnight by a slight modification of the method of Archer, Dormer, Scowan, and Watts (1957). By using a microsyringe (Agla) at the titration $10 \mathrm{ml}$ of urine was sufficient for the analysis. The titration was performed with 0.1 molar permanganate under continuous stirring in a $10 \mathrm{ml}$ test tube.
The mean recovery of oxalate added to different urine samples was around $80 \%$ (range $75-82 \%$ ). Calcium chloride added to a sample of freshly voided urine did not decrease the recovery of oxalate. When possible ( $90 \%$ of the determinations) duplicate samples were analysed. The difference between the two determinations was 2.4 (1 SD) $\mathrm{mg} / \mathrm{l}$ at a mean concentration of $40 \mathrm{mg} / \mathrm{l}$.

\section{OTHER METHODS}

The methods used for the determination of total fat and fatty acids in faeces, sodium and potassium in faeces, calcium in urine, faeces, and food, and total bile salt in duodenal samples will be reported elsewhere together with the results of these determinations.

The oxalic acid content of the diets have been calculated from food composition tables (Zarembski and Hodgkinson, 1962).

\section{Results}

THE URINARY OXALATE EXCRETION

This was $46 \pm 25$ (mean $\pm 1 \mathrm{SD}$ ) $\mathrm{mg} / 24 \mathrm{hr}$ in the 13 patients when the daily fat intake was $100 \mathrm{~g}$ compared with $20 \pm 7 \mathrm{mg}$ in the controls (table II). In 10 out of the 13 patients the excretion exceeded $34 \mathrm{mg} / 24 \mathrm{hr}$.

Faecal fat excretion was reduced (Andersson $e t$ $a l, 1974)$ when fat intake was decreased. Of the total faecal fat a mean of $80 \%$ (range $33-100 \%$ ) was comprised of free fatty acids while the content of triglycerides generally was low. A linear positive correlation was found between faecal fatty acid output and urinary oxalate excretion (fig $1, r=0.70$, $P<0.01)$ as well as between faecal fat output and oxalate excretion $(r=0.68, P<0.01)$. 


\begin{tabular}{|c|c|c|c|c|c|c|c|c|c|c|c|c|}
\hline \multirow[t]{4}{*}{ Patients $^{1}$} & 100-g Fat & \multicolumn{3}{|c|}{ 40-g Fat Diet } & \multirow{2}{*}{\multicolumn{3}{|c|}{$\begin{array}{l}\text { 100-g Fat } 40-\mathrm{g} \text { Fat Diet } \\
\text { Diet } \\
\begin{array}{l}\text { Initial } \\
\text { Study }\end{array}\end{array}$}} & \multirow{3}{*}{$\begin{array}{l}\text { Follow-up } \\
\text { Study } \\
\text { Mean } \\
\text { Four } \\
\text { Days }\end{array}$} & \multirow{3}{*}{$\begin{array}{l}\text { Before } \\
\text { Dietary } \\
\text { Treatment }\end{array}$} & \multirow{3}{*}{$\begin{array}{l}\text { 100-g Fat } \\
\text { Diet } \\
\text { Initial } \\
\text { Study }\end{array}$} & \multirow{3}{*}{$\begin{array}{l}\text { 40-g Fat } \\
\text { Diet } \\
\text { Initial } \\
\text { and } \\
\text { Follow-up } \\
\text { Studies }\end{array}$} & \multirow{3}{*}{$\begin{array}{l}\text { Fat- } \\
\text { reduced } \\
\text { Diet at } \\
\text { Home }\end{array}$} \\
\hline & \multicolumn{3}{|l|}{$\begin{array}{l}\text { Initial } \\
\text { Study }\end{array}$} & \multirow{2}{*}{$\begin{array}{l}\text { Follow-up } \\
\text { Study } \\
\text { Mean } \\
\text { Four } \\
\text { Days }\end{array}$} & & & & & & & & \\
\hline & $\begin{array}{l}\text { Mean } \\
\text { Whole } \\
\text { Period }^{2}\end{array}$ & $\begin{array}{l}\text { Mean } \\
\text { Whole } \\
\text { Period }^{8}\end{array}$ & $\begin{array}{l}\text { Mean } \\
\text { Last Four } \\
\text { Days }\end{array}$ & & $\begin{array}{l}\text { Mean } \\
\text { Whole } \\
\text { Period }^{8}\end{array}$ & $\begin{array}{l}\text { Mean } \\
\text { Whole } \\
\text { Period }\end{array}$ & $\begin{array}{l}\text { Mean } \\
\text { Last Four } \\
\text { Days }\end{array}$ & & & & & \\
\hline & \multicolumn{4}{|c|}{ Urinary Oxalate Excretion $(\mathrm{mg} / 24 \mathrm{hr})^{4}$} & \multicolumn{4}{|c|}{ Urinary Oxalate Concentration $(m g / 1)^{4}$} & \multicolumn{4}{|c|}{ Oxalate Content of the Diet $(\mathrm{mg} / 24 \mathrm{hr})$} \\
\hline $\begin{array}{l}\text { Group I } \\
\text { M } 210 \\
\text { M } 170 \\
\text { M } 209 \\
\text { M } 191 \\
\text { M } 203 \\
\text { M } 216 \\
\text { M } 195 \\
\text { M } 158\end{array}$ & $\begin{array}{r}100 \\
82 \\
38 \\
39 \\
61 \\
44 \\
47 \\
36\end{array}$ & $\begin{array}{l}51 \\
38 \\
33 \\
50 \\
30 \\
22 \\
53 \\
17\end{array}$ & $\begin{array}{l}49 \\
19 \\
30 \\
51 \\
21 \\
28 \\
46 \\
11\end{array}$ & $\begin{array}{l}\overline{24} \\
47 \\
23 \\
12 \\
40 \\
18\end{array}$ & $\begin{array}{l}96 \\
57 \\
36 \\
56 \\
90 \\
37 \\
69 \\
22\end{array}$ & $\begin{array}{r}31 \\
21 \\
31 \\
65 \\
33 \\
12 \\
22 \\
8\end{array}$ & $\begin{array}{r}29 \\
9 \\
27 \\
66 \\
26 \\
16 \\
19 \\
5\end{array}$ & $\begin{array}{r}\overline{11} \\
29 \\
18 \\
8 \\
19 \\
7\end{array}$ & $\begin{array}{r}75 \\
100 \\
15 \\
75 \\
45 \\
70 \\
20 \\
105\end{array}$ & $\begin{array}{r}265 \\
80 \\
30 \\
60 \\
40 \\
85 \\
35 \\
70\end{array}$ & $\begin{array}{r}55 \\
80 \\
35 \\
290 \\
40 \\
75 \\
70 \\
80\end{array}$ & $\begin{array}{r}\overline{110} \\
35 \\
- \\
30 \\
90 \\
50 \\
50\end{array}$ \\
\hline Mean \pm SD & $56 \pm 24$ & $37 \pm 14$ & $32 \pm 15$ & $27 \pm 13$ & $58 \pm 26$ & $28 \pm 17$ & $25 \pm 19$ & $15 \pm 8$ & $65 \pm 35$ & $85 \pm 75$ & $90 \pm 80$ & $60 \pm 30$ \\
\hline $\begin{array}{l}\text { Group II } \\
\text { M } 198 \\
\text { M } 179 \\
\text { M } 164 \\
\text { M } 211 \\
\text { M } 185\end{array}$ & $\begin{array}{l}13 \\
14 \\
19 \\
39 \\
61\end{array}$ & $\begin{array}{l}23 \\
11 \\
21 \\
39 \\
62\end{array}$ & $\begin{array}{l}14 \\
11 \\
17 \\
39 \\
63\end{array}$ & $\begin{array}{l}14 \\
19 \\
20 \\
11\end{array}$ & $\begin{array}{r}9 \\
10 \\
60 \\
63 \\
42\end{array}$ & $\begin{array}{r}14 \\
5 \\
44 \\
34 \\
42\end{array}$ & $\begin{array}{r}9 \\
4 \\
19 \\
28 \\
47\end{array}$ & $\begin{array}{r}8 \\
16 \\
6\end{array}$ & $\begin{array}{l}45 \\
40 \\
60 \\
35 \\
65\end{array}$ & $\begin{array}{l}65 \\
20 \\
30 \\
35 \\
50\end{array}$ & $\begin{array}{l}75 \\
30 \\
50 \\
65 \\
55\end{array}$ & $\begin{array}{r}45 \\
180 \\
- \\
40 \\
110\end{array}$ \\
\hline Mean $\pm \mathbf{S D}$ & $29 \pm 21$ & $31 \pm 20$ & $29 \pm 22$ & $16 \pm 4$ & $37 \pm 26$ & $28 \pm 17$ & $27 \pm 17$ & $10 \pm 4$ & $50 \pm 15$ & $40 \pm 20$ & $55 \pm 15$ & $95 \pm 65$ \\
\hline
\end{tabular}

Table II Urinary oxalate excretion, urinary oxalate concentration, and calculated oxalate intake at different dietary fat levels in 13 patients with ileal disease ${ }^{1}$

${ }^{1}$ Group I, patients with a faecal fat excretion $>15 \mathrm{~g} / 24 \mathrm{hr}$ and group II, patients with a fat excretion $<15 \mathrm{~g} / 24 \mathrm{hr}$ at a dietary fat intake of $100 \mathrm{~g}$ per day 'The duration of the study varied from four to 16 (mean 10) days for the difforent subjects.

'The duration of the study varied from 12 to 24 (mean 19) days for the different subjects.

The excretion in the control group $(n=13)$ was $20 \pm 7$ (mean $+\mathrm{SD}) \mathrm{mg} / 24 \mathrm{hr}$ and the concentration $16 \pm 7 \mathrm{mg} / \mathrm{l}$.

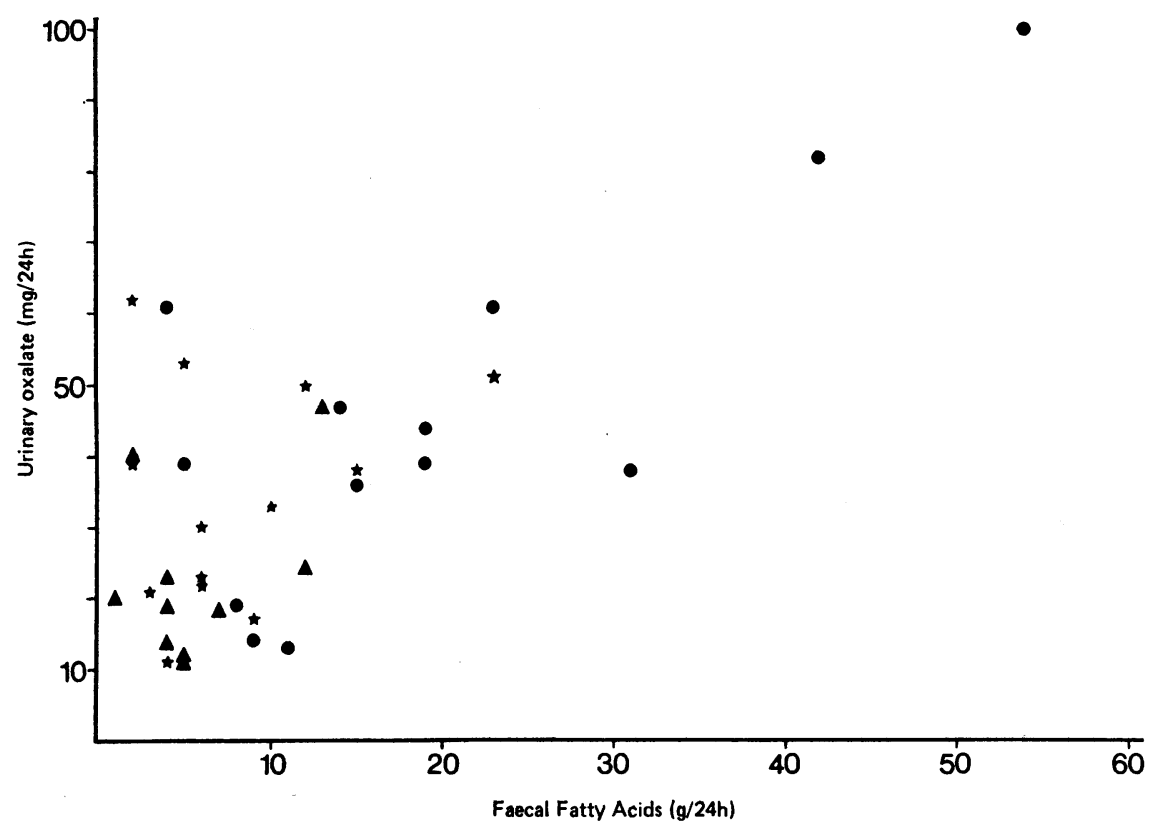

Fig 1 Correlation between urinary oxalate excretion and faecal fatty acid output in 13 patients with ileal disease during periods of varying fat intake. $\bigcirc=100 \mathrm{~g}$ dietary fat; $\star=40 \mathrm{~g}$ dietary fat, initial study; $\Delta=\mathbf{4 0} \mathrm{g}$ dietary fat, follow-up study 
Because of this finding the patient material was divided into two main groups (table II). Group I included eight patients with an initial faecal fat excretion exceeding $15 \mathrm{~g} / 24 \mathrm{hr}$ and group II five patients with an excretion less than $15 \mathrm{~g} / 24$ hours. In group I the urinary oxalate excretion decreased when the fat intake was reduced from $100 \mathrm{~g}$ to $40 \mathrm{~g}$ per day in five patients and was essentially unchanged in the remaining three. In the follow-up study the oxalate excretion remained low in patients on the fat-reduced diet except in M 209 who had a daily faecal fat excretion of $\mathbf{1 4} \mathrm{g}$. In group II a high oxalate excretion was observed initially in only two of the patients. In these patients no change in the oxalate excretion was observed during the initial study. However, during the follow-up study the daily excretion had decreased to 20 and $11 \mathrm{mg}$ respectively.

The patients had a higher diuresis when they were on the low-fat diet (Andersson et al, 1974) because the diarrhoea was reduced and finally ceased in all but the ileostomy patient. Thus the urinary oxalate concentration was proportionally more reduced than the excretion per unit time. The mean calculated oxalate intake was about the same on the highfat and fat-reduced diets but there were great variations in the different patients (table II). In patient
M 210 the decrease in oxalate intake may have influenced the decrease in urinary oxalate excretion and in patients M 191 and M 195 the fact that the oxalate excretion did not decrease may be explained by the increase in the oxalate content of the diet.

CORRELATION OF URINARY OXALATE WITH DIETARY, URINARY, AND FAECAL CALCIUM AND PHOSPHORUS EXCRETION

There was no correlation between the urinary oxalate excretion and the calcium intake in the patient material.

Urinary excretion of calcium was low in almost all patients (fig 2). An excretion of calcium exceeding $170 \mathrm{mg} / 24 \mathrm{hr}$ was not connected with hyperoxaluria and generally the patients with the lowest calcium excretion had the highest urinary oxalate excretion.

The mean daily faecal calcium excretion in the 13 patients ranged from 310 to 1300 (group mean $770) \mathrm{mg}$ on the high-fat diet and from 380 to 1590 (group mean 840) $\mathrm{mg}$ on the low-fat diet at a constant calcium intake between 200 and 1440 (mean group 810) and 290 and 1900 (group mean 1000) $\mathrm{mg} / 24 \mathrm{hr}$ respectively. One patient, M 185 , had a faecal calcium excretion of only 370 (intake 340 ) and 400 (intake 340 ) $\mathrm{mg}$ respectively on the two

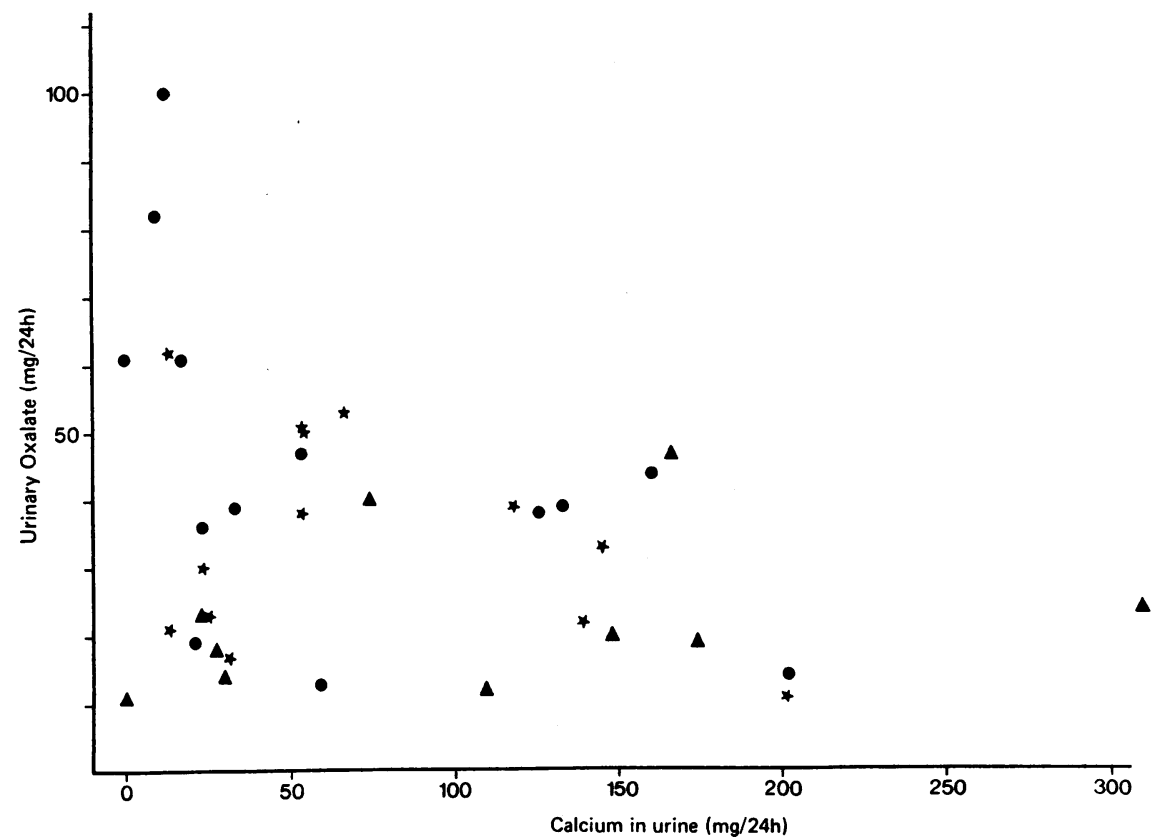

Fig 2 Urinary oxalate excretion in relation to urinary calcium excretion in 13 patients with ileal disease during periods of varying fat intake. $O=100 \mathrm{~g}$ dietary fat $; \hbar=40 \mathrm{~g}$ dietary fat, initial study; $\Delta=40 \mathrm{~g}$ dietary fat, follow-up study 


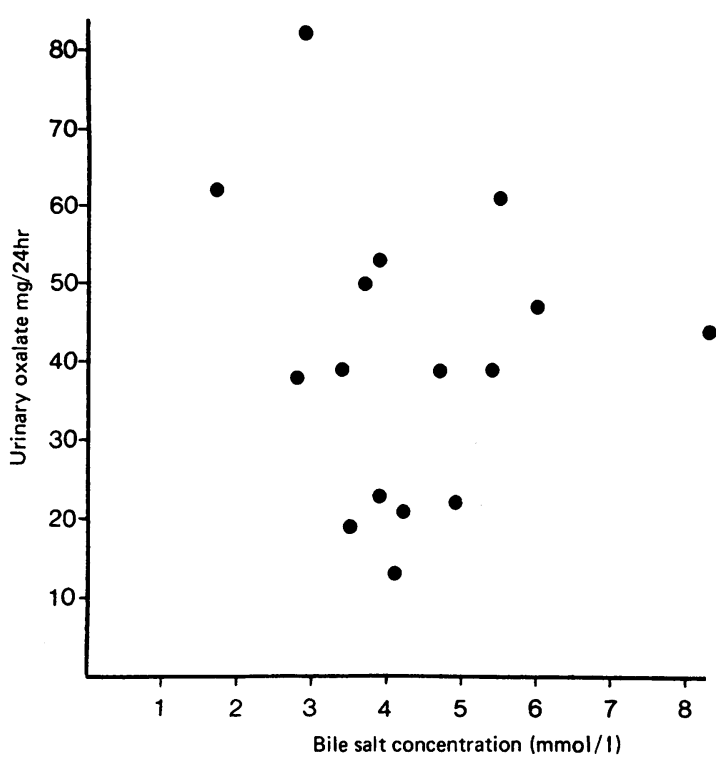

Fig 3 Urinary oxalate excretion in relation to total duodenal bile salt concentration in patients with ileal disease.

diets. The intake of oxalate was unchanged in this patient and the oxalate excretion did not decrease in spite of a low faecal fat excretion. The urinary calcium excretion in this patient was below $15 \mathrm{mg} / 24$ $\mathrm{hr}$ during the initial study. The oxalate excretion was found to have become normal at the follow-up study.

There was no correlation between faecal and urinary phosphorus excretion and the urinary oxalate excretion in the total patient material.

\section{CORRELATION OF URINARY OXALATE WITH} DUODENAL BILE SALT CONCENTRATION

AND FAECAL EXCRETION OF WATER, ELECTROLYTES, AND NITROGEN

The fat-reduced diet did not increase duodenal bile salt concentration (Andersson, 1974) and there was no correlation between the postprandial bile salt concentration (mean value of the three deteruinations) and the excretion of urinary oxalate (fig 3). There was no correlation between urinary oxalate excretion and faecal water, faecal electrolytes, and faecal nitrogen excretion.

\section{Discussion}

A fat-reduced diet has been found to reduce the diarrhoea in patients with ileal disease and in patients subjected to ileal resection (Booth, MacIntyre, and Mollin, 1964; Andersson et al, 1974). The present study shows that a reduction in the daily fat intake from $100 \mathrm{~g}$ to $40 \mathrm{~g}$ can after a short period of time reduce the urinary oxalate excretion, at least in patients with marked steatorrhoea. The results of the follow-up study indicate that a reduction in the fat intake might after a longer period of time reduce the oxalate excretion even in patients with a normal or almost normal faecal fat excretion.

The decrease in the oxalate excretion occurred when factors known to influence the excretion, such as the oxalate content of the diet (Chadwick et al, 1973) and the dietary calcium intake (Zarembski and Hodgkinson, 1969; Marshall, Cochran, and Hodgkinson, 1972), were relatively constant, and in spite of increased urinary volumes which are known to increase urinary oxalate excretion (Zarembski and Hodgkinson, 1969). The increased diuresis, which was due to a reduction in the stool water on the fatreduced diet, should further diminish the risk of forming renal calculi.

Increased absorption of dietary oxalate has been shown to be the cause of the hyperoxaluria in patients with ileal dysfunction (Chadwick et al, 1973). The mechanism for the increased absorption in this condition is not known but several explanations have been proposed (Chadwick et al, 1973; Stauffer et al, 1973). It has been shown that an increased oxalate absorption can be provoked by a reduction in the intake of calcium (Zarembski and Hodgkinson, 1969; Marshall et al, 1972). A possible mechanism is that the decrease in the calcium intake results in less calcium being available to form insoluble calcium oxalates in the intestine. Proportionately greater amounts of the ingested oxalic acid will therefore be present as soluble salts which can be absorbed (Marshall et al, 1972). In normal subjects (Marshall et al, 1972) and in patients with renal calculus (Zarmbski and Hodgkinson, 1969; Marshall et al, 1972) an increase in the urinary oxalate excretion occurs only when the calcium intake is markedly reduced. As there was no correlation between the oxalate excretion and the calcium intake in our material a low content of calcium in the diet does not seem to be the main cause of the hyperoxaluria.

The good correlation between the urinary oxalate excretion and the faecal fat and fatty acid content and the fact that only the subjects with the lowest urinary calcium excretion had hyperoxaluria favours the hypothesis that a high oxalate absorption is due to a low intraluminal calcium ion concentration caused by the formation of insoluble calcium soaps (Chadwick et al, 1973) (fig 4). A proportionately greater amount of the oxalate will then be in a soluble form.

On the other hand we have not been able to dem- 
NORMALLY

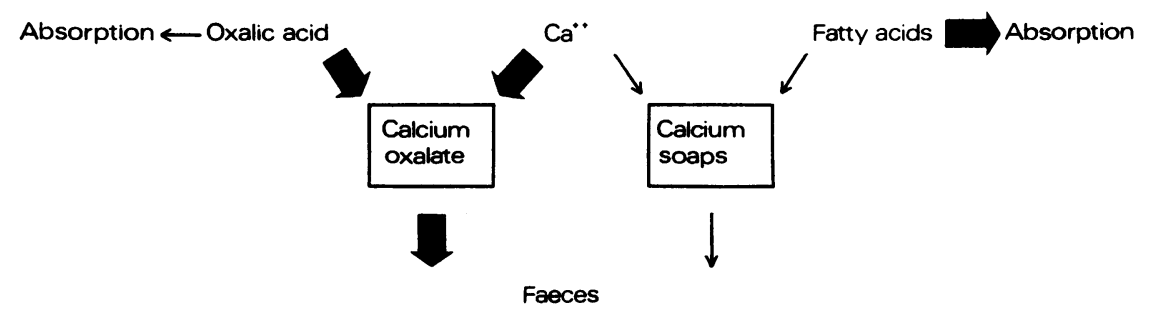

STEATORRHOEA IN ILEAL DISEASE

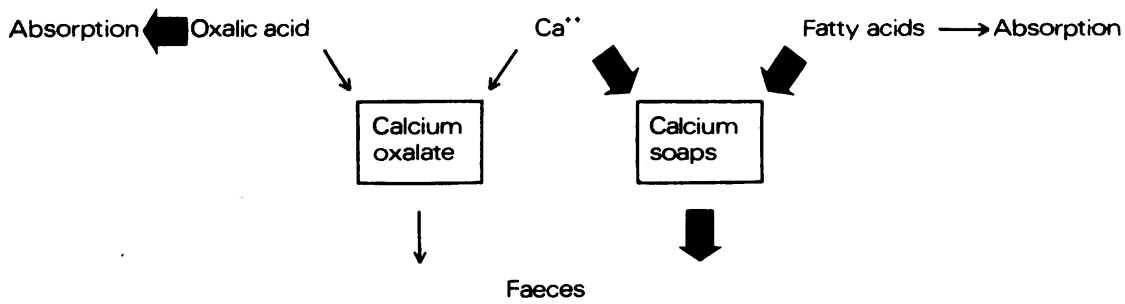

Fig 4 Proposed mechanism for the hyperoxaluria in patients with increased faecal excretion of fatty acids.

onstrate an inverse relationship between the duodenal bile salt concentration and the oxalate excretion. The theory that a reduced jejunal concentration of bile salts should cause the hyperoxaluria (Chadwick et al, 1973) therefore seems unlikely in our patients.

The patient without steatorrhoea (M 185) but with high oxalate excretion had a low calcium intake and an extremely low urinary calcium excretion, which may explain, at least partly, the hyperoxaluria in this patient.

The oxalate content of the diet might have contributed to a decrease in oxalate excretion in one patient and might explain why there was no decrease in two other patients after the introduction of the fatreduced diet.

Different treatments have been proposed for the reduction of the hyperoxaluria in patients with ileopathy. The use of taurine has already been mentioned in the introduction. Cholestyramine therapy is not recommended for patients with marked steatorrhoea (Hofmann and Poley, 1969) as it increases the steatorrhoea. The practical application of an oxalate-reduced diet, suggested by Chadwick et al (1973), has not yet been evaluated but from a nutritional point of view it is difficult to adhere to such a diet and it is not advisable as most vegetables must be excluded. A fat-reduced diet, as used in the present study, is effective both for reduction of the diarrhoea and of the urinary excretion of oxalate. It is also well tolerated, as six patients previously reported (Andersson, 1973) (three of them included in the present study) have now been on this dietary regime for two to six years.

This work was supported by the Swedish Medical Research Council (project no. 19 X-570).

\section{References}

Admirand; W. H., Earnest, D. L., and Williams, H. E. (1971). Hyperoxaluria and bowel disease. Trans. Ass. Amer. Phycns, 84, 307-212.

Andersson, H. (1973). Treatment of steatorrhea with fat-reduced diet in small-bowel disease. Bibl. 'Nutr. et Dieta.' (Basel), $19,64-69$.

Andersson, H. (1974). Effects of a fat-reduced diet on faecal excretion and duodenal concentration of bile salts in patients with ileal disease. To be published.

Andersson, H., Isaksson, B., and Sjögren, B. (1974). Fat-reduced diet in the symptomatic treatment of small bowel disease. Gut, 15, 351-359,

Archer, H. E., Dormer, A. E., Scowen, E. F., and Watts, R. W. E. (1957). Studies on the urinary excretion of oxalate by normal subjects. Clin. Sci., 16, 405-411.

Booth, C. C., MacIntyre, I., and Mollin, D. L. (1964). Nutritional problems associated with extensive lesions of the distal small intestine in man. Quart. J. Med., 33, 401-420.

Chadwick, V. S., Modha, K., and Dowling, R. H. (1973). Mechanism for hyperoxaluria in patients with ileal dysfunction. New Engl. J. Med., 289, 172-176.

Dowling, R. H., Rose, G. A., and Sutor, D. J. (1971). Hyperoxaluria and renal calculi in ileal disease. Lancet, 1, 1103-1106.

Hofmann, A. F., and Poley, J. R. (1969). Cholestyramine treatment of diarrhoea associated with ileal resection. New Engl. J. Med., 281, 397-402.

Hofmann, A. F., Thomas, P. J., Smith, L. H., and McCall, J. T. (1970). Pathogenesis of secondary hyperoxaluria in patients with ileal resection and diarrhea. (Abstr.) Gastroenterology, $58,960$.

Isaksson, B., and Sjögren, B. (1967). A critical evaluation of the mineral and nitrogen balances in man. Proc. nutr. Soc., 26, 106-116. 
Marshall, R. W., Cochran M., and Hodgkinson, A. (1972). Relationships between calcium and oxalic acid intake in the diet and their excretion in the urine of normal and renal-stone-forming subjects. Clin. Sci., 43, 91-99.

Smith, L. H., Fromm, H., and Hofmann, A. F. (1972). Acquired hyperoxaluria, nephrolithiasis, and intestinal disease. New Engl. J. Med., 286, 1371-1375.

Smith, L. H., Hofmann, A. F., McCall, J. T., and Thomas, P. J. (1970). Secondary hyperoxaluria in patients with ileal resection and oxalate nephrolithiasis. (Abstr.) Clin. Res., 18, 541.

Stauffer, J. Q., Humphreys, M. H., and Weir, G. J. (1973). Acquired hyperoxaluria with regional enteritis after ileal resection. Ann. intern. Med., 79, 383-391.

Zarembski, P. M., and Hodgkinson, A. (1962). The oxalic acid content of English diets. A. Brit. J. Nutr., 16, 627-634.

Zarembski, P. M., and Hodgkinson, A. (1969). Some factors influencing the urinary excretion of oxalic acid in man. Clin. chim. Acta 25, 1-10.

\section{The April 1974 Issue}

\section{THE APRIL 1974 ISSUE CONTAINS THE FOLLOWING PAPERS}

The control of bile acid pool size: Effect of jejunal resection and phenobarbitone on bile acid metabolism in the rat H. Y. I. MOK, P. M. PERRY, AND R. HERMON DOWLING

Bile salt metabolism in tropical sprue G. BEVAN, R. ENGERT, F. A. KLIPSTEIN, N. MALDONADO, A. RUBULIS, AND M. D. TURNER

Collagen proline hydroxylase activity and ${ }^{35} \mathrm{~S}$ sulphate uptake in human liver biopsies J. O'D. MCGEE, R. S. PATRICK, MARION C. RODGER, AND CAROLYN M. LUTY

Simplified cholangiography using ioglycamide G. J. S. PARKIN AND H. HERLINGER

Secretion of water and electrolytes into the duodenum in normal subjects and in patients with cirrhosis: The response to secretin and pancreozymin $\mathbf{L}$. A. TURNBERG AND G. GRAHAME

Cellular infiltrate of jejunal biopsies in adult coeliac disease in relation to gluten withdrawal G. $\mathbf{K}$. T. HOLMES, P. ASQUITH, P. L. STOKES, AND W. T. COOKE
Studies on the nature and significance of connective tissue antibodies in adult coeliac disease and Crohn's disease A. F. N. Magalhaes, T. J. PETERS, AND WILLIAM F. DOE

The dynamic structure of a flat small intestinal mucosa studied on the explanted rat jejunum c. A. LOEHRY AND R. GRACE

A study of peripheral leucocyte migration in agarose medium in inflammatory bowel disease WIroLD BARTNIK, E. T. SWARBRICK, AND CHRISTOPHER WILLIAMS

Rectal biopsy and precancer in ulcerative colitis H. E. MYRVOLD, N. G. KOCK, AND CHR. ÅHRÉN

\section{Technique}

The collection of pancreatic fluid for cytodiagnosis using a duodenoscope A. R. W. HATFIELD, R. WHITTAKER, AND D. D. GIBBS

Progress report Breath-analysis tests in gastroenterology A. NEWMAN

Progress report Iron and the liver MICHAEL BARRY The British Society of Gastroenterology

Notes and activities

Copies are still available and may be obtained from the PUBLISHING MANAGER,

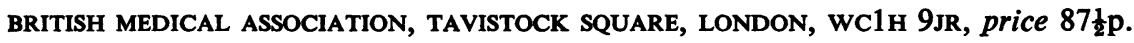

